\title{
THE APPLICATION OF THE DYNAMIC CLASSIFICATIONS IN ORDER TO EVALUATE THE CHANGES OF THE EUROPEAN UNION'S SUSTAINABLE DEVELOPMENT
}

Iwona Bak ${ }^{1}$, Associate Professor; Katarzyna Cheba ${ }^{2}, \mathrm{PhD}$

1,2 West Pomeranian University of Technology in Szczecin

\begin{abstract}
The main purpose of the paper is to analyse the changes over time in the area of sustainable development of the EU countries. To estimate these changes, the taxonomic measure of development based on the median Weber vector was used. The analyses presented in the paper utilize information on the indicators elaborated to monitor the implementation of the objectives of the EU Sustainable Development Strategy published by Eurostat from the year 2008 to 2014. As a result, the classification and the typological groups of EU countries with similar changes over time were presented. The value added of the research presented in the paper is the analyses of changes over time in the area of sustainable development of EU countries divided into two groups: the so-called old EU-15 countries and the countries which accessed the EU after 2004. Taking into account the influence of time into the considered changes, it may be possible, thanks to using relative compound annual growth rate, to point the countries in which an improvement in the area of sustainable development, countries with a constant level and those for which the deterioration of the situation could be observed.
\end{abstract}

Key words: sustainable development, median Weber vector, dynamic classification.

JEL code: C38, P11, P36

\section{Introduction}

The concept of sustainable development, which was first formulated explicitly during the Third UNEP Program in 1975 as "(...) such a course of inevitable and desirable economic development that would not materially and irreversibly affect the human environment and would not lead to the degradation of the biosphere and would not undermine the laws of nature, economics and culture"(UN, 1975), has since the beginning enjoyed considerable interest among researchers from various fields of science. The inclusion of economic issues in this definition has become the basis for formulating a broader concept of sustainable development. In the Brundtland Briefing Report of the World Commission on Environment and Development UN in 1987, sustainable development was defined as "sustainable development to meet current needs without the risk that future generations will not be able to meet their needs" (WCED, 1987). Over the years, sustainable development has been the subject of many analyses and studies. Zhu and Hua (2016) identified as many as 59 926 records (from 1987 to 2015) in the Web of Science on research into various areas of sustainability. A total of 149 different research areas were identified from 49 countries. A particular increase in the number of publications in this area concerns the last 10 years. Between 2012-2015, more than 6 thousand publications on various areas of sustainable development appeared (Zhu and Hua, 2016). So much interest in this subject proves the growing importance of sustainable development in different areas of human life. In spite of the existence of discussions on the interpretation of sustainability (Brown et al., 1987; Shearman, 1990; Redclift, 1992; Goodland, 1995; Piontek, 2002; Hopwood, Mellor and O'Brien, 2005), the concept of sustainable development had acquired a global cultural and social dimension. Much of the published material touches the issue of measuring sustainability (Borys, 2002, 2011; Dovers and Handmer, 2009). In this case, besides attempts to identify indicators that measure different aspects and areas of sustainable development, research is also needed to show how the results achieved in this area have changed over time. Studies of this kind are also important for socio-economic and political structures such as the European Union, which has monitored the development of individual countries in this area for years based on an extensive base of sustainable development indicators. 
References to the concept of sustainable development can be found in all EU strategic documents as well as in the studies compiled at the level of a particular EU Member State. An important area of research at all levels of this measurement (EU dimension, national, regional or local dimension) is anticipating the direction of EU development in this area.

The main purpose of the paper is to analyse the changes over time in the area of sustainable development of the EU countries and to divide EU countries into typological groups with similar dynamics of a studied phenomenon. In a dynamic classification, the relative compound annual growth rate calculated on the basis of median Weber vector was applied. The study used data from the year 2008 to 2014 available in the Eurostat database. Taking into account the influence of time on the studied area it may be possible to extract the countries in which you can see an improvement in the area of sustainable development, countries with a constant level (no changes over time) and those for which there is a deterioration of the situation. The paper consists of four sections. The first section is introduction. The second section is devoted to the methodological issues of empirical studies. The third section deals with empirical results of the research. The paper is closed with conclusions.

\section{Methodological issues of empirical studies}

The study presented in the paper was implemented through four tasks.

1) Creating a sustainable development (SD) indicators database of the European Union.

In the paper, SD indicators presented by Eurostat from the years 2008-2014 were used. The original data base included 124 indicators describing 10 themes of the European Union sustainable development. The primary criterion for the selection of indicators for the study was their availability during the analysed period. Due to gaps in the original database, Croatia was excluded, which means that the indicators for sustainable development were analysed in the 27 EU Member States.

2) Selection of diagnostic features.

In the next step, diagnostic features were selected for the study. After defining and gathering data concerning the initial set of features, proper verification is usually performed against two most important criteria: variability and correlation. Taking into account the former of the above criteria, 10 diagnostic features were eliminated from the study, because the coefficients of variation calculated for them were low throughout the whole period of study (at $10 \%$ or lower). In the next step, a parametric method proposed by Hellwig (1981) was used to select a final set of diagnostic features. It is the most commonly used method of diagnostic features selection. However, the method is not perfect: it is sensitive to outliers (or asymmetric distribution of features) and it takes into account only direct relationships of a given features with other ones, ignoring indirect relationships. Improved resistance of the method to outliers can be achieved by replacing in the first step the sum of elements in a column (or a row) of the correlation coefficient matrix by their median ${ }^{1}$. The final set of features according to proposal of Zelias (2000) was created by indicators whose frequency of occurrence was the highest in the whole analysed period. Finally, to this set of diagnostic features which are characterized by high spatial variability with low correlation within the selected indicators and asymmetric distribution, 20 diagnostic features were selected. The features in this set were divided into stimulants (S) and destimulants (D) ${ }^{2}$ as follows:

- in the area of socio-economic development: $x_{1 \mathrm{D}}$ - total unemployment rate $(\%, \mathrm{D})$,

${ }_{1}^{1}$ The second fault can be eliminated by means of the matrix inverse method (Nowak, 1990).

2 The stimulants are features whose bigger values indicate a higher level of progress of a given phenomenon, while the destimulants are features whose smaller values signify a higher level of development (Hellwig, 1968). 
- in the area of sustainable consumption and production: $x_{25}$ - resource productivity (Euro per kilogram, S), $x_{3 \mathrm{D}}$ - total emission of nitrogen oxides (NOx), (tonnes per $1 \mathrm{~km}^{2}, \mathrm{D}$ ),

- in the area of social inclusion: $x_{4 \mathrm{D}}$ - people living in households with very low work intensity $(\%, D), x_{5 D}$ - early leavers from education and training $(\%, D), x_{6 S}$ - tertiary educational attainment by sex, age group 30-34 ( \%, S), $x_{7 \mathrm{D}}$ - long-term unemployment rate $(\%, \mathrm{D}), x_{8 \mathrm{D}}-$ relative median at-risk-of-poverty gap $(\%, D), x_{9 D}-$ at most lower secondary educational attainment by age, from 25 to 64 years $(\%, D)$,

- in the area of demographic changes: $x_{10 D}$ - general government gross debt ( $\%$ of GDP), $x_{115}-$ aggregate replacement ratio $(\%, S), x_{12 S}$ - total fertility rate (number of children per woman, S),

- in the area of public health: $x_{13 \mathrm{D}}$ - people having a long-standing illness or health problem, by income quintile $(\%, D), x_{14 \mathrm{D}}$ - proportion of population living in households considering that they suffer from noise $(\%, D)$,

- in the area climate change and energy: $x_{15 s}$ - share of renewable energy in gross final energy consumption $(\%, S), x_{16 s}$ - share of renewable energy in fuel consumption of transport $(\%, S), x_{17 s}-$ combined heat and power generation, \% of gross electricity generation ( \% of gross electricity generation, $\mathrm{S})$,

- in the area of sustainable transport: $x_{18 D}$ - volume of freight transport relative to GDP ( \%, D),

- in the area of good governance: $x_{19 D}$ - shares of environmental in total tax revenues from taxes and social contributions ( $\%, D), x_{20 S}$ - level of citizens' confidence in EU institutions ( $\%, S$ ).

To the final set of diagnostic features, the indicators represented the areas of: natural resources (collected only for selected countries by Eurostat) and global partnership (represented by a very limited number of indicators) weren't introduced.

3) Construction of taxonomic measures of development based on median Weber vector.

The linear assignment of European Union countries was conducted using the method based on the median Weber (1971) vector ${ }^{1}$. The positional option of the linear object assignment takes a different normalization formula ${ }^{2}$, compared to the classical approach, based on a quotient of the feature value deviation from the proper coordinate of the Weber median and a weighed absolute median deviation, using the Weber median (Lira et al., 2002; Mlodak et al., 2016) ${ }^{10}$ :

$$
z_{i j}=\frac{x_{i j}-\theta_{0 j}}{1,4826 \cdot m \tilde{a} d\left(X_{j}\right)}
$$

where: $\theta_{0}=\left(\theta_{01}, \theta_{02}, \ldots, \theta_{0 \mathrm{~m}}\right)$ is the Weber median, $\operatorname{ma} \mathrm{d}\left(\mathrm{X}_{\mathrm{j}}\right)$ is the absolute median deviation, in which the distance from the features to the Weber vector is measured, ${ }^{3}$ i.e.: $\operatorname{mãd}\left(\mathrm{X}_{\mathrm{j}}\right)=\operatorname{med}_{\mathrm{i}=1,2, \ldots, \mathrm{n}}\left|\mathrm{x}_{\mathrm{ij}}-\theta_{0 \mathrm{j}}\right| \quad(j=1,2, \ldots m)$. The synthetic measure $\mu_{i}$ is calculated on the basis of maximum values of normalized features, similarly to the Hellwig (1968) method: $\varphi_{j}=\max _{i=1,2, \ldots, n} z_{i j}$, according to the following formula:

\footnotetext{
${ }^{1}$ The Weber median is a multi-dimensional generalization of the classical notion of the median. It is about vector that minimizes the sum of Euclidean distance (Euclidean distance) of the data points representing the considered objects, and therefore is somehow "in the middle" of them, but it is also immune to the presence of outliers (Weber, 1971).

2 The median Weber vector was calculated on the basis of features by transforming destimulants into stimulants on the basis of the following formula: $x_{i j}^{\prime}=1 / x_{i j}, I=1,2, \ldots, n ; j=1,2, \ldots, n$.

${ }^{3}$ The Weber median was calculated in $R$ program: I1median of package: $p c a P P$.
} 


$$
\mu_{i}=1-\frac{d_{i}}{d_{-}}
$$

where: $\mathrm{d}_{-}=\operatorname{med}(\mathbf{d})+2,5 \operatorname{mad}(\mathbf{d})$, where $\mathbf{d}=\left(d_{1}, d_{2}, \ldots, d_{n}\right)$ is a distance vector calculated with

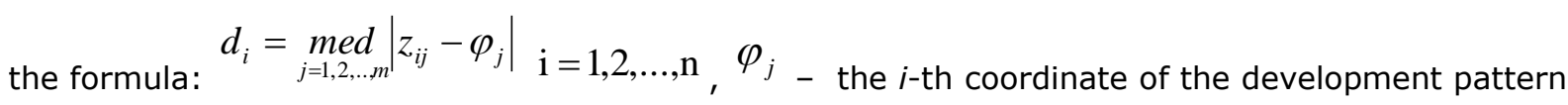
vector, which is constituted of the maximum values of the normalized features.

4) Dynamic classification based on the values of relative compound annual growth rate ( $r C A G R, \%)$ estimated on the basis of taxonomic measures of development in 2008-2014.

To calculate the values of relative compound annual growth rate the following formula was used:

$$
r C A G R_{i}=\left(C^{\prime} A G R_{i}-1\right) * 100 \%,(i=1, \ldots, 27)(3),
$$

where: $C A G R$ - compound annual growth rate for $i$-th country calculated as follows:

$$
\text { CAGR }_{i}=\sqrt[n-1]{\sqrt{\frac{\mu_{i_{n}}}{\mu_{i_{1}}}}},(i=1, \ldots, 27 ; n=1, \ldots, 7)
$$

On the basis on $r C A G R_{i}$ the division of population of objects into three groups in the following way can be provided: a) group I: $r C A G R_{i}>0$, b) group II: $r C A G R_{i}=0$, c) group III: $r C A G R_{i}<0$.

The first group comprises objects for which results of $r C A G R_{i}$ are on the over zero level, it means that the improvement in the level of development of these objects in a studied area can be observed. The second group is represented by the objects with a constant level of development, which means no significant changes in studied area. While to the third group the objects characterizing by the deterioration of the situation were classified. Groups: first and third can be also divided into two subgroups: a) subgroup I includes countries for which: ${ }^{P C A G R_{1}}>\bar{x}_{\bar{V} C A G R_{1}} ; \mathrm{b}$ ) subgroup II - countries for which: ${ }^{P C A G R_{i}} \leq \bar{x}_{\mathrm{rCAGR}_{2}}$, where: $\bar{x}_{\mathrm{PCAGR}_{1}}$ is the mean value in the first group, while $\bar{x}_{\mathrm{rCAGR}_{2}}$ in the third one.

\section{Research results and discussion}

Table 1 shows the results of the classification of the EU countries obtained by means of the taxonomic measure of development calculated on the basis of the sustainable development features. The results of classification were divided into two groups: a) EU Member States, belonging to the so called "old 15" and b) EU Member States, belonging to the so called "new members". This way of presentation of EU countries classification allows to analyse the differences before and after EU enlargement. The results of the research confirmed that the assignment of EU countries to typological groups does not depend on the moment of joining the EU. These observations confirmed the previous analysis of the authors (Szopik-Depczynska et al., 2017). In these studies, it was noticed that after the economic crisis of 2007-2008, the previous division of EU countries into so-called old and new EU Member States presented in many scientific papers does not correspond with the current EU situation. It means that the "new" EU Member States usually coped better with the economic slowdown. The same conclusions were formulated by the think-tanks of the Central European Policy Institute (2014). 
The results of the ranking (value, rank and rCAGR) in 2008-2014

Table 1

\begin{tabular}{|c|c|c|c|c|c|c|c|c|c|}
\hline \multicolumn{2}{|c|}{ Country } & 2008 & 2009 & 2010 & 2011 & 2012 & 2013 & 2014 & $\begin{array}{c}\text { rCAGR } \\
(2009-2014, \%)\end{array}$ \\
\hline \multicolumn{10}{|c|}{ EU Member States, belonging to the so called "old 15" } \\
\hline \multirow{2}{*}{ Austria } & $\mu_{i}$ & 0.864 & 0.550 & 0.406 & 0.548 & 0.571 & 0.585 & 0.676 & \multirow{2}{*}{4.23} \\
\hline & rank & 8 & 5 & 13 & 5 & 6 & 12 & 5 & \\
\hline \multirow{2}{*}{ Belgium } & $\mu_{i}$ & 0.825 & 0.510 & 0.481 & 0.428 & 0.475 & 0.475 & 0.567 & \multirow{2}{*}{2.14} \\
\hline & rank & 16 & 7 & 6 & 14 & 15 & 18 & 13 & \\
\hline \multirow{2}{*}{ Denmark } & $\mu_{i}$ & 0.894 & 0.595 & 0.570 & 0.508 & 0.532 & 0.457 & 0.586 & \multirow{2}{*}{-0.29} \\
\hline & rank & 3 & 4 & 4 & 10 & 9 & 20 & 11 & \\
\hline \multirow{2}{*}{ Finland } & $\mu_{i}$ & 0.868 & 0.600 & 0.613 & 0.649 & 0.657 & 0.728 & 0.751 & \multirow{2}{*}{4.60} \\
\hline & rank & 7 & 3 & 3 & 3 & 3 & 5 & 3 & \\
\hline \multirow{2}{*}{ France } & $\mu_{i}$ & 0.872 & 0.539 & 0.528 & 0.514 & 0.594 & 0.627 & 0.665 & \multirow{2}{*}{4.28} \\
\hline & rank & 6 & 6 & 5 & 8 & 4 & 8 & 6 & \\
\hline \multirow{2}{*}{ Greece } & $\mu_{i}$ & 0.788 & 0.317 & 0.236 & 0.129 & 0.126 & 0.075 & 0.271 & \multirow{2}{*}{-3.07} \\
\hline & rank & 22 & 22 & 25 & 27 & 27 & 27 & 27 & \\
\hline \multirow{2}{*}{ Germany } & $\mu_{i}$ & 0.773 & 0.337 & 0.290 & 0.347 & 0.430 & 0.486 & 0.529 & \multirow{2}{*}{9.46} \\
\hline & rank & 26 & 20 & 21 & 21 & 18 & 17 & 16 & \\
\hline \multirow{2}{*}{ Ireland } & $\mu_{i}$ & 0.855 & 0.340 & 0.321 & 0.348 & 0.420 & 0.583 & 0.586 & \multirow{2}{*}{11.53} \\
\hline & rank & 9 & 19 & 20 & 20 & 19 & 13 & 12 & \\
\hline \multirow{2}{*}{ Italy } & $\mu_{i}$ & 0.800 & 0.297 & 0.242 & 0.385 & 0.363 & 0.398 & 0.410 & \multirow{2}{*}{6.65} \\
\hline & rank & 21 & 23 & 24 & 17 & 22 & 21 & 22 & \\
\hline \multirow{2}{*}{$\begin{array}{l}\text { Luxembour } \\
\text { g }\end{array}$} & $\mu_{i}$ & 0.899 & 0.765 & 0.706 & 0.774 & 0.759 & 0.822 & 0.902 & \multirow{2}{*}{3.35} \\
\hline & rank & 2 & 1 & 2 & 1 & 2 & 2 & 1 & \\
\hline Netherland & $\mu_{i}$ & 0.825 & 0.480 & 0.459 & 0.520 & 0.518 & 0.597 & 0.594 & 436 \\
\hline $\mathbf{s}$ & rank & 17 & 9 & 8 & 7 & 13 & 9 & 9 & (10 \\
\hline Portugal & $\mu_{i}$ & 0.766 & 0.246 & 0.252 & 0.252 & 0.321 & 0.259 & 0.410 & 1079 \\
\hline & rank & 27 & 24 & 23 & 25 & 23 & 25 & 23 & 20. \\
\hline Spain & $\mu_{i}$ & 0.783 & 0.236 & 0.235 & 0.326 & 0.169 & 0.239 & 0.292 & 4.28 \\
\hline & rank & 23 & 25 & 26 & 23 & 26 & 26 & 26 & 1.20 \\
\hline Sweden & $\mu_{i}$ & 0.938 & 0.699 & 0.764 & 0.757 & 0.817 & 0.853 & 0.832 & 355 \\
\hline 19. & rank & 1 & 2 & 1 & 2 & 1 & 1 & 2 & כת.ני \\
\hline United & $\mu_{i}$ & 0.835 & 0.380 & 0.324 & 0.391 & 0.374 & 0.359 & 0.539 & 725 \\
\hline Kingdom & rank & 13 & 15 & 19 & 15 & 20 & 23 & 14 & (2) \\
\hline & & Membc & States, & belongi & to the & o callec & new m & nbers" & \\
\hline Bulgaria & $\mu_{i}$ & 0.783 & 0.366 & 0.445 & 0.329 & 0.291 & 0.375 & 0.404 & 195 \\
\hline 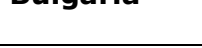 & rank & 24 & 17 & 9 & 22 & 24 & 22 & 24 & (1.0 \\
\hline Cvprus & $\mu_{i}$ & 0.827 & 0.490 & 0.413 & 0.354 & 0.445 & 0.472 & 0.505 & 0.61 \\
\hline & rank & 14 & 8 & 12 & 19 & 16 & 19 & 20 & 年 \\
\hline Czech & $\mu_{i}$ & 0.821 & 0.427 & 0.400 & 0.459 & 0.520 & 0.743 & 0.508 & 3.54 \\
\hline Republic & rank & 18 & 12 & 16 & 12 & 12 & 3 & 18 & זית \\
\hline Estonia & $\mu_{i}$ & 0.878 & 0.464 & 0.404 & 0.379 & 0.539 & 0.729 & 0.660 & 7.28 \\
\hline 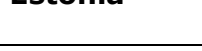 & rank & 5 & 10 & 15 & 18 & 8 & 4 & 7 & $1 .<0$ \\
\hline Hungary & $\mu_{i}$ & 0.814 & 0.372 & 0.405 & 0.390 & 0.434 & 0.498 & 0.523 & 7.03 \\
\hline & rank & 20 & 16 & 14 & 16 & 17 & 16 & 17 & \\
\hline & $\mu_{i}$ & 0.818 & 0.177 & 0.286 & 0.303 & 0.371 & 0.595 & 0.647 & 29.5 \\
\hline & rank & 19 & 26 & 22 & 24 & 21 & 10 & 8 & ת. \\
\hline
\end{tabular}




\begin{tabular}{|c|c|c|c|c|c|c|c|c|c|}
\hline \multicolumn{2}{|c|}{ Country } & \multirow{2}{*}{$\begin{array}{l}2008 \\
0.889\end{array}$} & \multirow{2}{*}{$\begin{array}{l}2009 \\
0.329\end{array}$} & \multirow{2}{*}{$\begin{array}{l}2010 \\
0.380 \\
\end{array}$} & \multirow{2}{*}{$\begin{array}{l}2011 \\
0.574 \\
\end{array}$} & \multirow{2}{*}{$\begin{array}{l}2012 \\
0.475 \\
\end{array}$} & \multirow{2}{*}{$\begin{array}{l}2013 \\
0.644 \\
\end{array}$} & \multirow{2}{*}{$\begin{array}{l}2014 \\
0.712 \\
\end{array}$} & \multirow{3}{*}{$\begin{array}{c}\text { rCAGR } \\
\text { (2009-2014, \%) } \\
16.68\end{array}$} \\
\hline \multirow{2}{*}{ Lithuania } & $\mu_{i}$ & & & & & & & & \\
\hline & rank & 4 & 21 & 18 & 4 & 14 & 7 & 4 & \\
\hline \multirow{2}{*}{ Malta } & $\mu_{i}$ & 0.777 & 0.020 & 0.172 & 0.226 & 0.226 & 0.340 & 0.385 & \multirow{2}{*}{80.49} \\
\hline & rank & 25 & 27 & 27 & 26 & 25 & 24 & 25 & \\
\hline \multirow{2}{*}{ Poland } & $\mu_{i}$ & 0.841 & 0.411 & 0.441 & 0.459 & 0.521 & 0.541 & 0.594 & \multirow{2}{*}{7.61} \\
\hline & rank & 12 & 14 & 10 & 13 & 11 & 15 & 10 & \\
\hline \multirow{2}{*}{ Romania } & $\mu_{i}$ & 0.843 & 0.417 & 0.472 & 0.512 & 0.586 & 0.688 & 0.497 & \multirow{2}{*}{3.57} \\
\hline & rank & 11 & 13 & 7 & 9 & 5 & 6 & 21 & \\
\hline \multirow{2}{*}{ Slovakia } & $\mu_{i}$ & 0.827 & 0.356 & 0.399 & 0.493 & 0.531 & 0.573 & 0.507 & \multirow{2}{*}{7.30} \\
\hline & rank & 15 & 18 & 17 & 11 & 10 & 14 & 19 & \\
\hline \multirow{2}{*}{ Slovenia } & $\mu_{i}$ & 0.849 & 0.434 & 0.439 & 0.521 & 0.560 & 0.587 & 0.532 & \multirow{2}{*}{4.14} \\
\hline & rank & 10 & 11 & 11 & 6 & 7 & 11 & 15 & \\
\hline
\end{tabular}

Source: author's calculations based on Eurostat data

The information in the Table 1 shows also that the classifications of EU countries are not stable over time. The positions occupied by individual EU countries in the rankings in many cases differed significantly. Taking into account the beginning and the end of the period considered, only five countries (Bulgaria, the Czech Republic, France, Lithuania and Malta) did not change their positions in the studied years. It should be noted that it does not mean that their positions were constant throughout the considered period. It is worth noting that only ten EU Member States noted an improvement in sustainability in 2014 compared to 2008. Over $50 \%$ of the EU countries recorded a decline in the ranking in this period, with the highest in Romania (10 ranks down, from $10^{\text {th }}$ position to $21^{\text {st }}$ ), Denmark ( 8 down, from $3^{\text {rd }}$ to $11^{\text {th }}$ ) and Cyprus ( 6 down, from $14^{\text {th }}$ to $20^{\text {th }}$ ). Between 2008 and 2014, the highest (first and second) positions were alternately occupied by Sweden and Luxembourg. The significant divergences in the rankings were noted for many countries e.g.: Bulgaria, which in 2008 was in the $24^{\text {th }}$ position, two years later it improved by fifteen positions in order to fall again in 2011 to $24^{\text {th }}$ position. The improvement was recorded in 10 countries, the most in Latvia (from $19^{\text {th }}$ to $8^{\text {th }}$ ) and in Germany (from $26^{\text {th }}$ to $16^{\text {th }}$ ). Greece, Malta and Spain were usually classified on the last positions in the rankings. In the next step dynamic classification based on the values of compound annual growth rate according to the last step of the research methodology was provided. It should be noted that the values of taxonomic measures of development in 2008 for all EU countries are significantly different from others. The decline of these measures from 2009 is probable the result of the world economic crisis from 2007-2008. Taking into account the above information, the values of compound annual growth rate were calculated on the basis of data from 2009-2014.

Figure 1 presents the results of assignment of EU countries to typological groups according the results of relative compound annual growth rate. To the first group EU countries characterizing by the improvement in the level of sustainable development were classified. This group is made up of almost all EU countries (excluding Denmark and Greece). Due to significant differences in the values of designated measures for individual EU countries, it was decided to divide this group into two subgroups (first with the value of rCAGR over the mean for this group and second below this value). To the first subgroup $5 \mathrm{EU}$ countries with the results of $r C A G R$ over $10 \%$ were classified as

${ }_{1}^{1}$ The geometric mean on the basis of which the relative compound annual growth rate is determined belongs to the group of classical average measures sensitive to outliers. 
follows: Malta, Latvia, Lithuania, Ireland and Portugal but the highest improvement (rCAGR $>80 \%$ ) for Malta was observed. While the second subgroup by 20 EU countries (both by countries belonging to EU-15 and so called "new members") was made. In this subgroup, the lowest increase of the rCAGR for Cyprus was observed ( $r C A G R=0.61 \%)$.

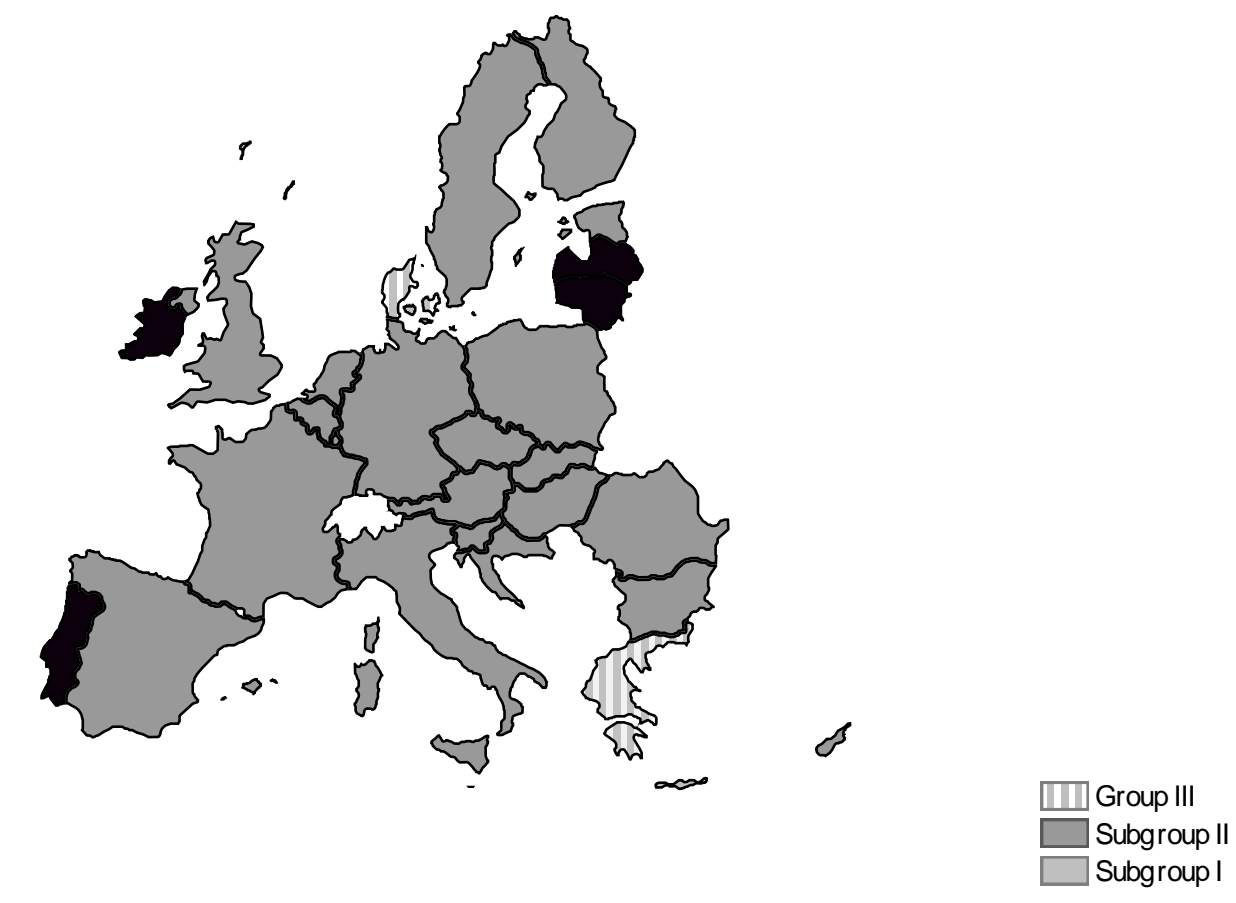

Source: author's calculations based on Eurostat data

Fig. 1. Division of EU countries into the typological groups according the rCAGR

\section{Conclusions}

On the basis of study results presented in the paper the following conclusions can be formulated.

1) The paper attempts to identify trends of changes in the area of sustainable development in EU countries and to distinguish typological groups of objects with similar dynamics of the studied phenomenon. The results of the presented research and analyses confirm the observations in the literature on the differences in the development of the EU. The economic crisis of 2007/2008 led to significant changes in the ranking of EU countries due to sustainable development. Therefore, when analysing the dynamics of sustainable development using the relative compound annual growth rate, it was decided to include only the period 2009-2014.

2) Almost all of the analysed EU countries were classified into the first group, characterized by an improvement in the area of sustainable development. Nevertheless, due to significant differences in the relative compound annual growth rate (almost $80 \mathrm{pp}$ ) within the first group, the EU countries were divided into those for which the relative compound annual growth rate is above and below the value of mean. It turned out that despite the increase in the taxonomic value of development, and thus the positive relative compound annual growth rate, the positions of EU countries in the rankings were not significantly improved in most cases. This was due to the fact that the increase in the value of taxonomic measures concerned the majority of EU Member States. 
3) The division of the EU countries into groups according to time of accessing to European Union can't be treated as a criterion of classification. Almost all of analysed EU countries were classified into first group characterized by improvement of the change over time in the area of sustainable development.

4) The results obtained in this study can be used in subsequent years to verify the direction of changes in sustainable development levels observed both from the point of view of the EU Member States and groups of these countries divided according to the time of accessing to EU.

\section{Bibliography}

1. Borys, T. (2002). Wskazniki rozwoju zrownowazonego. Podstawowe kierunki badan i zastosowan, (Indicators of sustainable development. Basic directions of research and applications), Ekonomia i Srodowisko, No. 1(21), pp. 39-59.

2. Borys, T. (2011). Zrownowazony rozwoj - jak rozpoznac lad zintegrowany, (Sustainable development - how to recognize integrated order), Problemy Ekorozwoju: studia filozoficzno-socjologiczne, No. 6(2), pp. 75-81.

3. Brown, B., J., Hanson, M., E., Liverman, D., M., Merideth, R., W., Jr. (1987). Global Sustainability: Toward Definition, Environmental Management, No. 11(6), pp. 713-719.

4. Central European Policy Institute. (2014). Central Europe fit for the future, Bratislava and Warsaw.

5. Dovers, S., R., Handmer, J., W. (2009). Contradictions in Sustainability, Environmental Conservation, NO. 20(3), pp. 217-222.

6. Goodland, R. (1995). The Concept of Environmental Sustainability, Annual Review of Ecology and Systematics, No. 26, pp. 1-24, http://www.jstor.org/stable/2097196.

7. Hellwig, Z. (1968). Zastosowanie metody taksonomicznej do typologicznego podzialu krajow ze wzgledu na poziom ich rozwoju oraz zasoby i strukture wykwalifikowanych kadr, (Application of the taxonomic method to the typological division of countries due to the level of their development and the resources and structure of qualified personnel), Przeglad Statystyczny, No. 4, pp. 12-25.

8. Hellwig, Z. (1981). Wielowymiarowa analiza porownawcza i jej zastosowanie w badaniach wielocechowych obiektow gospodarczych, (Multidimensional comparative analysis and its application in studies of multitechnical economic objects), PWE, Warszawa.

9. Hopwood, B., Mellor, M., O'Brien, G. (2005). Sustainable Development: Mapping Different Approaches, Sustainable Development, No. 13(1), pp. 38-52.

10. Lira, J., Wagner, W., Wysocki, F. (2002). Mediana w zagadnieniach porzadkowania obiektow wielocechowych, (Median in the problems of organizing multi-feature objects), [w:] J. Paradysz (red.), Statystyka regionalna w sluzbie samorzadu lokalnego i biznesu, Internetowa Oficyna Wydawnicza Centrum Statystyki Regionalnej, Akademia Ekonomiczna w Poznaniu, Poznan, pp. 87-99.

11. Mlodak, A., Jozefowski, T., Wawrowski, L. (2016). Zastosowanie metod taksonomicznych w estymacji wskaznikow ubostwa, (Application of taxonomic methods in estimation of poverty indicators), Wiadomości Statystyczne, R. LXI, 2, pp. 1-24.

12. Nowak, E. (1990). Metody taksonomiczne w klasyfikacji obiektow spoleczno-gospodarczych, (Taxonomic methods in the classification of socio-economic objects), PWE, Warszawa.

13. Piontek, B. (2002). Koncepcja rozwoju zrownowazonego i trwalego, (The concept of sustainable and durable development), PWN, Warszawa.

14. Redclift, M. (1992). The Meaning of Sustainable Development, Geoforum, No. 23(3), pp. 395-403.

15. Shearman, R. (1990). The Meaning and Ethics of Sustainability, Environmental Management, No. 14(1), pp. 1-8.

16. Szopik-Depczynska, K., Cheba, K., Bak, I., Kiba-Janiak, M., Saniuk, S., Dembinska, I., Ioppolo, G., (2017). The applications of relative taxonomy to the study of disproportions in the area of sustainable development of the European Union, Land Use Policy, 68, pp. 481-491.

17. UNEP. (1975). Declaration of the United Nations Conference on the Human Environment, United Nations Environment Programme (UNEP), Stockholm. www.unep. org., retrieved 2016-10-22.

18. Weber, A. (1909, reprint 1971). Theory of Location of Industries, Russel \& Russel, New York.

19. World Commission on Environment and Development (WCED). (1987). Raport Brundtland. Our Common Future, Oxford, Oxford University Press, New York.

20. Zelias, A. (ed.). 2000. Taksonomiczna analiza przestrzennego zroznicowania poziomu zycia $w$ Polsce $w$ ujeciu dynamicznym, (Taxonomic analysis of spatial differentiation of living standards in Poland in dynamic terms), AE, Kraków.

21. Zhu, J., Hua, W. (2016). Visualizing the Knowledge Domain of Sustainable Development Research between 1987 and 2015: a Bibliometric Analysis, Research Team on Sustainable Development Wuhan University, Wuhan China. 